\title{
DIVERSITY IN RETURNS TO EDUCATION IN EUROPE. THE EMPIRICAL IMPORTANCE OF THE SYSTEMS OF THE REGRESSION APPROACH
}

The aim of the paper is the formal comparison of returns to education for a set of European countries. We apply the system of Seemingly Unrelated Regression Equations (SURE) to obtain the parameters of the Mincerian equations. The differences between the parameters were tested given two alternative stochastic assumptions. In the first model, no contemporaneous correlations between error terms in the system are imposed. In the second approach, the unrestricted covariance matrix is considered, making error terms stochastically dependent. The contemporaneous correlations of error terms in the SURE system were empirically supported. The rich parameterisation of the covariance matrix of contemporaneous relations reduced statistical uncertainty about differences in parameters describing return to education. Therefore, the country heterogeneity of return on education, which seems intuitively correct, was obtained in the system of regressions with a complex stochastic structure.

Keywords: Mincer equation, returns to education, SURE, Zellner estimator

JEL Classifications: J31, C31

DOI: $10.15611 /$ aoe.2018.2.03

\section{INTRODUCTION}

The relationship between earnings and investment in education has been obvious since "The Wealth of Nations" was published in 1776 by Adam Smith. In particular Smith claimed that part of the time spent at the craft by the master together with the apprentice is devoted to training activity rather than production. Thus Smith, formulating the roots of scientific insight into economic processes, highlighted the importance of the investment in on-the job training.

The issues of human capital have been analysed by many economists despite the serious problems with the formal theoretical framework and the measurement. The pioneer trials of the quantitative assessment of the human

\footnotetext{
* Department of Econometrics and Operations Research, Cracow University of Economics.

** Department of Macroeconomics, University of Łódź.
} 
capital and estimation of the impact on the distribution of wages were performed by Mincer (1958). In this seminal paper the author underlined that human capital itself (as measured by the level of skills and abilities of an individual) is a non-measurable variable. However, he introduced the concept of investments in human capital interpreted as the process of learning and gaining abilities. Mincer identifies two kinds of investments in human capital, namely the investments in formal education (measured by years of schooling completed) and investments during the working life (measured by years of work experience). The contribution of Mincer to the research on human capital is enormous. He analysed both the impact of the individual schooling, as well as the work experience, on the properties of the distribution of earnings. Additionally, wages seem to increase with schooling level, age and occupational hierarchy (see Chiswick and Mincer, 2003, pp. 5-8).

The theoretical background that enables to describe formally the economic impact of human abilities on wages is the Mincer model. It assumes a quadratic dependence between the logarithm of the expected earnings and the given number of years of schooling. According to the Mincer model the earnings of an individual is an increasing function of the level of education, as measured by the years of formal schooling. Also, it is an increasing and concave function of experience, measured simply by the age of the individual. The original version of the Mincer model was subject to many generalisations. According to Lemieux (2006), the most important generalisation concerns the much more complicated nonlinear relationship between the rates of returns from human capital investment and earnings. Despite many generalisations, it seems that the Mincer model is still the basis for the empirical analyses of wage distribution as well as the relation between wages and existing human capital ${ }^{1}$.

One can also point out some disadvantages of the Mincer model. First, the model does not consider other determinants of wages, except for the level of education and work experience. Furthermore, it is possible to educate oneself and work simultaneously. It is worth mentioning that reflecting such a case in economic data is nearly impossible.

Initially Mincer estimated rates of returns from on-the-job training and their impact on the wage distribution for several different occupations. He showed that earnings profiles imply a decline in on-the-job training

\footnotetext{
${ }^{1}$ The human capital earnings function has become a technique accepted, for example, by the courts in analyses of earnings. It is used to estimate the value of lost earnings due to injury or death or resulting from discrimination (see Chiswick, 2003, p. 25).
} 
investments with age. Mincer also showed that on-the-job training investments increase with the level of schooling. The Mincer concept prompted new studies, however the necessity of some modification of the model was crucial. For example, the nonlinear relationship between wages and schooling received particular attention; Lemieux, 2006, p. 4, and many others.

Starting from Mincer (1974), the issues of wage and human capital distribution have been studied by many authors. The empirical analyses indicate that the rate of return on education is equal or less than $10 \%$ of initial income per additional year of education or $30-35 \%$ for achieving a higher level. Several reviews of the empirical results can be found in the literature; see Psacharopoulos (1994), Psacharopoulos and Patrinos (2004), Hanushek and Woessmann (2010), Strauss and de La Maisonneuve (2007). Initially, in the problem of the estimation of the return on education, the simple linear regression with OLS estimator has been commonly used; see Becker and Chiswick (1966) and Mincer (1974). In the last decade the quantile regression estimator was also used by, among others, Ning (2010), Newell and Reilly (2001). There are, however, numerous contesting opinions in the literature expressing reservations towards the empirical results based on simple econometric frameworks. The issue of selection problems and heterogeneity in returns was addressed by Carneiro and Heckman (2002) and Blundell, Dearden and Sianesi (2005). Also, the decision made by individuals to take on more education involves many factors like individual ability, family background and preferences, which may be measured imprecisely. The endogeneity and causality problems in labour market studies was addressed by Heckman (1974), Heckman et al. (2006, 2008), Li and Tobias (2011). The impact of these effects on the return on education was discussed by Card (2001). Also, the importance of the observed and unobserved heterogeneity in the estimation of the return on education parameters was analysed by Willis and Rosen (1979). As the heterogeneity seems to be a serious and interesting issue, its analyses were performed according to particular education levels (see Aakvik et al., 2010) as well as different groups (Henderson et al., 2011) and parameters' estimates (Koop, Tobias, 2004).

Parameters of the Mincer regression are estimated using both individual and aggregated data observed for a country by labour force or employers' surveys. On the macro level, Mincerian equations were estimated on the basis of regressions for both cross-section data and time series; see Hausman and Taylor (1981), Moretti (2004), Krueger and Lindahl (2001). The main 
assumption for the cross-sectional analysis is the homogeneity of the regression parameters. Consequently, the impact of education and the experience on the observed wages do not vary across countries or across any groups of individuals.

Cross-country regressions were also performed by Hanushek and Zhang (2006), and more recently by Hanushek et al. (2015), Montenegro et al. (2014) and Roszkowska (2014). They reported country heterogeneity of returns to human capital analysing its estimated values varying across countries. The authors applied a multilevel modelling strategy, building regression of resulted returns to skills variability on alternative skill measures (like numeracy, literacy, problem-solving and others). However, a detailed insight into the significance of the observed returns to skill differences is missing. Since the stochastic assumptions imposed in the underlying regression models may be different, the issue of formal statistical testing if observed returns to skill are different, is important.

The main goal of the paper is to estimate Mincerian equation parameters and to formally conclude about the heterogeneity of the return on education effect across European countries. We check if the standard econometric panel regression strategy is correct in the view of the aggregated data. Since the panel data approach relies on the imposed constancy of the return on education effect across the analysed set of countries, we relax this assumption in our research. The variability of parameters describing the impact of years of schooling to the wages, results from the application of the system of Seemingly Unrelated Regression Equations (SURE). Recently this classic yet very promising approach to modelling heterogeneity has received particular attention in cases of convergence analysis or the relationship between credit and growth; see Pipień and Roszkowska (2018) and Olszak and Pipień (2016), respectively.

In this paper the differences between parameters are subject to a testing procedure. In the first model, we assume that there are no contemporaneous correlations between error terms in the system. The second approach assumes the non-zero correlations in the covariance matrix of the error terms. We discuss the results of the testing and provide a classification of a set of European countries with respect to the strength of the return on education effect. Moreover, we indicate plausible reasons for that diversification. 


\section{PARAMETER HETEROGENEITY IN WAGE EQUATION}

The basic Mincer wage equation is as follows:

$$
\ln \text { wage }_{t}=\alpha_{0}+\alpha_{1} e d u_{t}+\alpha_{2} \text { age }_{t}+\alpha_{3} \text { age } e_{t}^{2}+\varepsilon_{t}, \quad t=1, \ldots, T,
$$

where $\ln$ wage $_{t}$ is the logarithm of the hourly wage observed in $t$-th major occupation group, while $a g e_{t}$ and $e d u_{t}$ describe age and the average level of education of the group. According to Mincer (1974) and Heckman et al. (2006), when specific measures of post-school investment are unavailable, potential work experience can be approximated simply by age. In Zoghi (2010), Lacuesta et al. (2011), Bolli and Zurlinden (2012), Nilsen et al. (2011), the age or work experience variables are used only up to the particular age group because observations on the exact number of years corresponding with those variables are not available.

The parameters of interest are $\alpha_{2}$ and $\alpha_{3}$, describing the impact of the age to the salary. Parameter $\alpha_{1}$ informs us about the strength of the return on education effect. Suppose we observe the aforementioned variables for $j$-th country $(j=1, \ldots, n)$ and we want to formulate the Mincer equation with structural parameters that vary across countries. Let us consider the following system of regressions:

$$
\ln w_{a g e_{t j}}=\alpha_{0 j}+\alpha_{1 j} e d u_{t j}+\alpha_{2 j} a g e_{t j}+\alpha_{3 j} a g e_{t j}^{2}+\varepsilon_{t j}, \quad j=1, \ldots, n,
$$

where $j$ denotes the number of a country. The error term $\varepsilon_{t j}$ in (2) captures the impact of effects not involved with the age and the average level of education of the group, to the variability of wage. These effects may concern country specific structural or institutional conditions, cultural differences, the distribution of talents and others. Hence the proper stochastic assumptions in (1) and (2) are crucial when modelling the relationship between wage and the level of education. In the regression (2), having its roots in the Mincer theory, the endogeneity problem can be met, particularly with reference to the education variable. To resolve that problem, estimation techniques utilising instrumental variables (IV approach) can be applied. However, as suggested in Dickson and Harmon (2011) and Heckman and Urzua (2010), IV estimates rest on strong a priori data assumptions and the results may vary with respect to different sets of instruments applied in the estimation. 
The standard assumption that, for each $t$, Gaussian error terms $\varepsilon_{t j}$ in (2) are uncorrelated, makes the system of equations independent. This case, denoted by $M_{0}$, formally refers to the standard empirical strategy when country Mincer regressions are estimated separately. However, in general, error terms $\varepsilon_{t j}$ may exhibit cross correlation and system (2) can be treated as a Seemingly Unrelated Regression Equations (SURE) model. This case we define as $M_{1}$. Nonzero contemporaneous correlations of error terms in (2) define an ampler stochastic structure and enables testing formally $M_{0}$ as a special case. Also, the standard interpretation of nonzero contemporaneous correlations is used as indicators describing linkages in the variability of a related variable across countries.

Denote by $\varepsilon_{t}=\left(\varepsilon_{t 1}, \ldots, \varepsilon_{t n}\right)$ the row vector of error terms at time $t$ with the covariance matrix $\Sigma$. In the case of model $M_{1}$ the matrix $\Sigma$ is symmetric and positive definite with $n(n+1) / 2$ free elements $\sigma_{i j}^{2}, i=1, \ldots, n$ and $j=1, \ldots, n$. Standard notation gives the variance of the error terms in $i$-th country as $\sigma_{i i}^{2}>0$ and covariance between error terms in $j$-th and $i$-th country denoted by $\sigma_{i j}^{2}$. The system of equations (2) can be written in the following standard regression form:

$$
y^{(j)}=x^{(j)} \alpha^{(j)}+\varepsilon^{(j)}, \quad j=1, \ldots, n,
$$

where $y^{(j)}=\left(y_{1 j}, \ldots, y_{T j}\right)^{\prime}, x^{(j)}=\left(x_{1 j}{ }^{\prime}, \ldots, x_{T j}{ }^{\prime}\right)^{\prime}$, with $x_{t j}=\left(1, e d u_{t j}, a g e_{t j}, a g e_{t j}^{2}\right)$, $\varepsilon^{(j)}=\left(\varepsilon_{1 j}, \ldots, \varepsilon_{T j}\right)^{\prime}$ and $\alpha^{(j)}=\left(\alpha_{0 j}, \alpha_{1 j}, \alpha_{2 j}, \alpha_{3 j}\right)^{\prime}$. In the next step we stack the observations expressing the system of regression equations in the closed form:

$$
Y=X \alpha+\varepsilon,
$$

where $Y_{[n T x 1]}=\left(y^{(1)}, \ldots, y^{(n) \prime}\right)^{\prime}, \varepsilon_{[n T x 1]}=\left(\varepsilon^{(1) \prime}, \ldots, \varepsilon^{(n) '}\right)^{\prime}, \alpha_{[n 4 x 1]}=\left(\alpha^{(1)},, \ldots, \alpha^{(n) '}\right)^{\prime}$, and:

$$
X_{[n T x n 4]}=\left(\begin{array}{cccc}
x^{(1)} & 0_{[T x 4]} & \cdots & 0_{[T x 4]} \\
0_{[T x 4]} & x^{(2)} & \ddots & \vdots \\
\vdots & \ddots & \ddots & 0_{[T x 4]} \\
0_{[T x 4]} & \cdots & 0_{[T x 4]} & x^{(n)}
\end{array}\right) .
$$


Simple calculations yield the form of covariance matrix for the error term $\varepsilon$ in (3):

$$
V(\varepsilon)=\Sigma \otimes I_{n},
$$

where $\otimes$ denotes the Kronecker product. The form of the covariance matrix of $\varepsilon$ makes system (3) a generalised linear regression. Given $\Sigma$, the Aitken Generalised Least Squares estimator of all parameters in the system can be expressed in the following form:

$$
\hat{\alpha}_{G L S}=\left(X^{\prime}\left(\Sigma \otimes I_{n}\right)^{-1} X\right)^{-1} X^{\prime}\left(\Sigma \otimes I_{n}\right)^{-1} y,
$$

with the covariance matrix of the estimator given as follows:

$$
V(\hat{\alpha})=\left(X^{\prime}\left(\Sigma \otimes I_{n}\right)^{-1} X\right)^{-1} .
$$

In the case $M_{0}$, where $\Sigma=\operatorname{diag}\left(\sigma_{11}^{2}, \ldots, \sigma_{n n}^{2}\right)$, we have:

$$
\hat{\alpha}=\hat{\alpha}_{O L S}=\left(X^{\prime} X\right)^{-1} X^{\prime} y,
$$

which is equivalent to the application of $O L S$ estimator for each equation separately. In general case, $M_{1}$, we have to estimate covariance matrix $\Sigma$. In the empirical part of the paper we apply the Zellner (1962) method, and estimate elements of matrix $\Sigma$ based on OLS residuals, denoted by $\hat{\varepsilon}_{[n T x]}=\left(\hat{\varepsilon}^{(1)}{ }^{\prime}, \ldots, \hat{\varepsilon}^{(n) \prime}\right)^{\prime}$. The estimated $G L S$, proposed by Zellner (1962) takes the form:

$$
\hat{\alpha}_{E G L S}=\left(X^{\prime}\left(S \otimes I_{n}\right)^{-1} X\right)^{-1} X^{\prime}\left(S \otimes I_{n}\right)^{-1} y,
$$

with approximated small sample covariance matrix of the estimator:

$$
\hat{V}\left(\hat{\alpha}_{E G L S}\right)=\left(X^{\prime}\left(S \otimes I_{n}\right)^{-1} X\right)^{-1},
$$

where

$$
S=\frac{1}{T}\left(\hat{\varepsilon}^{(1)}, \ldots, \hat{\varepsilon}^{(n)}\right)^{\prime}\left(\hat{\varepsilon}^{(1)}, \ldots, \hat{\varepsilon}^{(n)}\right) .
$$

The empirical importance of the system of regressions is confirmed when matrix $\mathrm{S}$ indicates that $\Sigma$ is not diagonal. This is clearly implied by possible cross correlations of error terms. Another important issue making the system 
analysis possible and nontrivial is the form of the matrix of explanatory variables $X$. In the case of a system of regressions (3), the same matrix of explanatory variables is applied in each equation, namely for each $j=1, \ldots, n$ we have $x^{(j)}=x$. Consequently, matrix $X$ takes the form:

$$
X_{[n T x n 4]}=\left(\begin{array}{cccc}
x & 0_{[T x 4]} & \cdots & 0_{[T x 4]} \\
0_{[T x 4]} & x & \ddots & \vdots \\
\vdots & \ddots & \ddots & 0_{[T x 4]} \\
0_{[T x 4]} & \cdots & 0_{[T x 4]} & x
\end{array}\right)=x \otimes I_{n} .
$$

This extremely simplifies the method of estimation since by some basic properties of the Kronecker product we get:

$$
\begin{gathered}
\hat{\alpha}_{G L S}=\left(\left(x \otimes I_{n}\right)^{\prime}\left(\Sigma \otimes I_{n}\right)^{-1}\left(x \otimes I_{n}\right)\right)^{-1}\left(x \otimes I_{n}\right)^{\prime}\left(\Sigma \otimes I_{n}\right)^{-1} y= \\
=\left(X^{\prime} X\right)^{-1} X^{\prime} y=\hat{\alpha}_{O L S}
\end{gathered}
$$

This result holds irrespective of whether the covariance matrix is diagonal or unrestricted. However, in the analysed case of matrix $X$, the difference between estimation with the use of $\hat{\alpha}_{G L S}$ and $\hat{\alpha}_{O L S}$ is subtler and concerns the form of the covariance matrices. Since $\hat{\alpha}_{O L S}$ results from the assumption that matrix $\Sigma$ is diagonal, the small sample approximation of the covariance matrix of the estimator $\hat{\alpha}_{O L S}$ is of a similar form as in the case of $\hat{\alpha}_{\text {OLS }}$, but the diagonal matrix $S_{\text {diag }}=\operatorname{diag}\left(s_{11}^{2}, \ldots, s_{n n}^{2}\right)$ is applied as estimator of $\Sigma=\operatorname{diag}\left(\sigma_{11}^{2}, \ldots, \sigma_{n n}^{2}\right)$ :

$$
\hat{V}\left(\hat{\alpha}_{O L S}\right)=\left(X^{\prime}\left(S_{\text {diag }} \otimes I_{n}\right)^{-1} X\right)^{-1},
$$

with $s_{j j}^{2}=\frac{1}{T} \hat{\varepsilon}^{(j)} \hat{\varepsilon}^{(j)} j=1, \ldots, n$. The diagonal elements of $\hat{V}\left(\hat{\alpha}_{O L S}\right)$ and $\hat{V}\left(\hat{\alpha}_{E G L S}\right)$ are the same and hence the inference about standard errors of structural parameters is the same. However, matrix $\hat{V}\left(\hat{\alpha}_{E G L S}\right)$ is not a block diagonal, and in the case of estimation of functions of interest involving regression parameters from different equations, the inference in the case of $E G L S$ may not be equivalent to the $O L S$ case. 
In the empirical part of the paper we test for the statistical significance of differences between parameters describing return on education, namely $\alpha_{1 j}$ for $j=1, \ldots, n$ across countries; see equation (2). We will perform it according to the standard testing procedure that involves the estimation of a linear combination of structural parameters. Suppose we are interested in a linear combination of structural parameters in (3) of the form $\gamma=c_{[n 4 x 1]} \cdot \alpha_{[n 4 x 1]}=\left(c^{(1)}, \ldots, c^{(n)}\right) \cdot\left(\alpha^{(1)},, \ldots, \alpha^{(n)}\right)^{\prime}$. . Vector $c_{[n 4 x 1]} \quad$ contains coefficients of a linear combination and is known. We define the $E G L S$ and $O L S$ estimator of the function of interest $\gamma$ as follows:

and

$$
\hat{\gamma}_{\text {OLS }}=c \cdot \hat{\alpha}_{\text {OLS }}
$$

$$
\hat{\gamma}_{E G L S}=c \cdot \hat{\alpha}_{E G L S} .
$$

The small sample approximations of the variance of estimators are given as follows:

$$
\hat{V}\left(\hat{\gamma}_{O L S}\right)=c \cdot \hat{V}\left(\hat{\alpha}_{O L S}\right) \cdot c^{\prime}
$$

and

$$
\hat{V}\left(\hat{\gamma}_{E G L S}\right)=c \cdot \hat{V}\left(\hat{\alpha}_{E G L S}\right) \cdot c^{\prime} .
$$

If the linear combination $\gamma$ involves parameters from different equations, the variance obtained on the basis of the $O L S$ estimator is different from the one obtained according to the EGLS procedure. This may cause different results of inference about $\gamma$, particularly in cases of testing the significance of some restrictions.

The aforementioned procedure can be applied for system (2) in testing the country heterogeneity of parameters. Suppose we are interested in testing whether the difference between return on education in $i$-th country is significantly different from the return on education in $j$-th country. More formally we are interested in testing the following hypothesis framework:

$$
\begin{aligned}
& H_{0}: \alpha_{1 i}-\alpha_{1 j}=0 \\
& H_{1}: \alpha_{1 i}-\alpha_{1 j} \neq 0 .
\end{aligned}
$$

This can be conducted on the basis of the function $\gamma^{i j}=c_{[n 4 x 1]} \cdot \alpha_{[n 4 x 1]}$, with $c_{[n 4 x 1]} \cdot\left(c^{(1)}{ }^{\prime}, \ldots, c^{(n)}{ }^{\prime}\right)$ such that $c^{(i)}=(0,1,0,0), \quad c^{(j)}=(0,-1,0,0)$ and 
$c^{(m)}=(0,0,0,0)$ for all remained, namely for $m \in\{1, \ldots, n\} \backslash\{i, j\}$. In this case, the $\gamma^{i j}$ simply means difference between $\alpha_{1, i}$ and $\alpha_{1, j}$, and testing country heterogeneity can be equivalently performed on the basis of the following testing hypothesis:

$$
\begin{aligned}
& H_{0}: \gamma^{i j}=0 \\
& H_{1}: \gamma^{i j} \neq 0 .
\end{aligned}
$$

The standard procedure of Student's $t$-test can be applied, with the test statistics utilising the standard errors defined as square roots of $\hat{V}\left(\hat{\gamma}_{E G L S}\right)$ in the case of an EGLS estimation procedure or of $\hat{V}\left(\hat{\gamma}_{O L S}\right)$ in the case of a simpler method, based on the $O L S$ estimator. It is interesting how the form of matrix $\Sigma$ influences the results of testing the heterogeneity of parameters. In the empirical part of the paper we perform those tests, making comparison of results in both cases of the form of matrix $\Sigma$.

\section{EMPIRICAL ANALYSIS}

The empirical analysis presented in the paper is based on the crosssection series taken from the European Union Structure of Earnings Survey (SES), a large representative enterprise sample survey. The SES provides comparable information on the level of remuneration and characteristics of employees such as sex, age and occupation. The analysed dataset contains reliable data on wages and not declared like in the case of data gathered from labour force surveys (LFS). Additionally, LFS may not be representative, because the survey is not obligatory and hence a large refusal rate (sometimes even more than 50\%) with regards to the question about the salary may occur. However, as the majority of workers are employed in enterprises with at least ten employees (see Table 4) and the structures of employment across the analysed countries do not differ substantially, we do not expect serious impact of this drawback.

The business activities included in the survey are those from enterprises operating in sections $\mathrm{B}$ to $\mathrm{S}$, excluding $\mathrm{O}$, according to NACE Rev. 2; see Table 5 in Appendix for a detailed description. The selection of the sample and conducting the survey is prepared by national statistics offices. The invaluable advantage of the survey is the credibility of data concerned with individuals' wages. Contrary to data from Labour Force Survey (LFS), the data on remuneration concerns the real data coming from employers and not 
those declared by respondents. We do not have access to the observed individual wages from the SES and hence in the empirical analysis we consider partially aggregated information, covering average wage corresponding to the particular occupational group and appropriate age group.

The structure and distribution of remunerations can be described by the human capital level. The available dataset contains information about occupation. It can be easily utilised to obtain approximated values of the education level. The occupation (profession) is defined as a set of tasks and duties characterized by their high degree and similarity. The profession needs suitable skills and knowledge. A skill is defined as the ability to carry out the tasks and duties of a given job (see International Standard Classifications: ISCO-08, 2012). According to ISCO-08 we separate four major levels of skills. Skill levels are defined by considering the level of education and qualifications gained by on-the-job training or practice. The key factor for the classification of professions is the level of required qualifications rather than the way of achieving them. According to ISC-08 methodology, there are four levels of skills (see Table 1). The first level requires elementary qualifications and primary or the first stage of basic education. The second level involves individuals with secondary levels of education (basic vocational, general and vocational comprehensive) and post or non-tertiary levels. The third level is related to education accomplished in the first stage tertiary education. The fourth level covers individuals with tertiary level of education.

Table 2 presents the basic descriptive statistics of wages in selected EU countries in 2010. The highest average hourly remunerations (ca. 18-19 PPS) can be observed in Denmark, Ireland and Belgium. The lowest (almost three times lower) are reported in Bulgaria, Romania and Latvia. In the old EU15 countries (except for Portugal), wages were higher than the average of the sample. The similar pattern can be found when studying the diversity of wages. Country statistics show the highest variation of wages in southern European countries (Portugal, Italy, Romania, Bulgaria and Slovenia). The lowest coefficients of variation (below 0.3) were discovered in Denmark and Sweden.

Analysis of wages by skill level (Table 6 in Appendix) shows that the lowest and the least diversified are the earnings in the group with a primary level of education. Higher and more diversified wages can be determined in the group of better qualified workers. The group of those with tertiary education is the most heterogeneous. This set includes, among others, executive professionals, legislators, teachers, medical doctors and artists. 
The group of employees with a secondary level of education is also moderately heterogeneous. This group includes clerical support workers, sales workers and machine operators. The study of wages by age in the set of analysed countries (Table 7) indicates the relatively moderate diversification (coefficient of variation equals from 0.3 to 0.4 ) in the first two age intervals (namely less than 30 years and from 30 to 39 years). Higher wages and higher variation $(\mathrm{cv}=0.5)$ appear in the group of employees aged 40 .

The preliminary, qualitative analyses (see Tables 2,6 and 7) indicate that the existing diversification of wages in Europe with respect to the level of skills and labour market experience is strong. Also, higher wages are observed together with a higher level of human capital accumulated by individuals. Our research strategy considers those empirical effects. Consequently, we estimate the total impact of changes in human capital on the wage level in European countries.

The parameters of regression equation (2) were subject to estimation. We assume that $e d u_{t j}$ is the mean skill level according to ISCO-08 of the employee in $t$-th major occupation group in country $j$; $a g e_{t j}$ - work experience measured by age interval of the employee in $t$-th major occupation group in country $j$ (there are five intervals for age: $2-$ less than 30 years, 3 - from 30 to 39 years, 4 - from 40 to 49 years, 5 - from 50 to 59 years, $6-60$ years or over); $\alpha_{0 j}$ - intercept for country $j ; \alpha_{1 j}$ - shows the relative change of worker's salary caused by skills' level increase; $\alpha_{2 j}, \alpha_{3 j}-$ show the impact of work experience on wages. The parameters of the above equation were estimated OLS using cross-section data (64 observations for every country) concerning men and women in 2010 in $22 \mathrm{EU}$ countries $^{2}$.

The results of the estimation are presented in Table 3 and estimated returns on education in Figure 1. In Table 3 we put the point estimates, standard errors (in italics) and $p$-values for the zero restriction test of a particular parameter (in square brackets). There is a positive and statistically significant impact of skill level on remuneration. Depending on the country of region, the improvement of skill level resulted in a $17-46 \%$ change of salaries. The estimated value of $\alpha_{1 j}$ parameter can be treated as a measure of returns to education in $j$-th country. As was mentioned above, the skill level can be easily mapped to education level.

The results in Table 3 demonstrate that the highest returns to education were in NMS countries and Portugal. These economies are characterized by

\footnotetext{
${ }^{2}$ From the whole sample of EU countries, the following had to be removed due to missing data: Luxembourg, Lithuania, Croatia, Cyprus and Malta.
} 
relatively low wages and high dispersion of wages (see Table 2). Moreover, the labour force in these countries is characterized by relatively worse educational attainment in tertiary degree and lower labour productivity as compared to other countries (Figures 2 and 3). Additionally, total public expenditures on education (as \% of GDP) are lower in these countries (Figure 7). The labour force participation in NMS countries and Portugal also seems lower than in the core EU15 (Figure 4). The obtained results for the 22 European countries converged on the increasing returns to education in selected emerging economies outcomes (see Münich et al., 2005; Vujčić, Šošić, 2009; Li et al.,2013; Bargain et al., 2009).

The lowest rates of return to education (17-19\%) can be found in Denmark and Sweden. Relatively low rates (under 30\%) are in the Netherlands, Finland, Ireland, Belgium and France. The labour force in this group of countries is well educated, expenditures on education are relatively substantial and the wages are relatively high and less diversified. In most of the analysed countries the work experience plays a significant role in wage formation. We consider nonlinear dependency between wages and work experience (resulting from the extended Mincer equation). In general, the level of wages can be described by the quadratic function of individuals' work seniority. Each additional year of work experience relates to an increase in the wage, however this effect stays true until the maximum level of remuneration is reached. Then the average wage ceases rising. The differences in returns to work experience are also diversified among countries. Although direct economic interpretation of estimated $\alpha_{2 j}$ parameter as return to work experience is not allowed due to nonlinearities, we can see that the distribution of these estimates is like that for $\alpha_{1 j}$ values. The lowest values are in NMS countries and the highest in the core EU15.

The system of regressions (2) enables us to formally test differences in parameters across countries. In particular, we are interested in testing whether the parameters describing return on education $\left(\alpha_{1 j}\right)$, are heterogeneous across countries. Those parameters were individually statistically significant, however a detailed insight into its heterogeneity across countries is subject to analysis. We perform a series of tests of the form (5) in pairs given two alternative assumptions imposed on the distribution of the error terms. The results of the tests are compared when a diagonal matrix with different variances attached to error terms for a particular country is considered, and alternatively, when the covariance matrix $\Sigma$ is unrestricted. In both cases, the point estimates of parameters, as well as its individual standard errors are the same in the case of OLS and 
Zellner estimator, however the inference about functions of interests involving parameters from different equations may be different due to the highly non-zero estimates of the off-diagonal elements of $\Sigma$; see Table 8 .

In the analysed framework $M L$ estimates are equivalent for the OLS procedure in model $M_{0}$ and the Zellner method in model $M_{1}$. Hence to compare the explanatory power of competing specifications we put in Table 3 the likelihood values at $M L$ estimates, together with model information criteria (AIC and BIC). It is clear that model $M_{1}$ receives decisive data support compared to model $M_{0}$ as the value of the log-likelihood reaches value 1889.709 against value 543.590 attached to the $M L$ estimates in model $M_{0}$. We performed a likelihood ratio test of the model $M_{0}$ in the null hypothesis obtained as a result of imposing appropriate zero restrictions of matrix $\Sigma$ in $M_{1}$. The resulted p-value obtained for $\Sigma$ distribution with 231 degrees of freedom ${ }^{3}$ is less than $10^{-8}$. This clearly indicates the empirical importance of the general mode framework $M_{1}$. The information criteria AIC and BIC also confirm empirical support in favour of model $M_{1}$ in spite of the number of free elements in the unconstrained case of matrix $\Sigma$.

The main results of the testing procedures are presented in Figures 5 and 6. We depict the groups of countries with similar, statistically indistinguishable return on education effect. In cases of countries with the same shading there was no data evidence against the zero hypothesis in (5) at 5\% significance level. The results presented on Figure 5 were obtained in cases of diagonal covariance matrix $\Sigma$, while Figure 6 is related to the unrestricted case. In the case of diagonal covariance matrix, the results of country heterogeneity of return on education are vague and are attributed with great uncertainty. Consequently we identify only two groups of countries with the same effect. The first group consists of Denmark and Sweden, while in the second group the rest of the countries are included. The statistical uncertainty about the differences between the parameters describing return on education in a particular country is substantial. Hence, given the simple stochastic structure of the model, it is impossible to categorize countries in a nontrivial way.

In more complex stochastic assumptions, with unrestricted covariance matrix $\Sigma$ (see Figure 6), we can distinguish five groups of countries with a statistically similar return on education parameter. In the first group, with the lowest return on education, we still have Denmark and Sweden, but the rest of the countries are split into four groups, separable from the statistical point

\footnotetext{
${ }^{3}[n \times n]$ covariance matrix $\sum$ can be restricted to diagonal case by imposing $0.5 n(n+1)-n$ restrictions.
} 
of view. The Netherlands, Finland, Ireland, Belgium and France are in the second group, while Spain, Latvia, Austria, Germany, Italy, the United Kingdom, Slovakia, the Czech Republic and Estonia constitute the third group. Hungary, Poland, Slovenia and Bulgaria constitute the fourth group, and Romania and Portugal the last group, representing countries with the highest return to education.

\section{CONCLUSIONS}

The main goal of the paper was to estimate the Mincer equation across European countries. The variability of parameters describing the impact of years of schooling (both formal at school and informal in workplace) to wages, was obtained by the application of a system of seemingly unrelated regression equations. We tested formally the differences between the parameters describing returns to formal education. In the first step, no contemporaneous correlations between error terms in the system are imposed, while in the second approach the unrestricted covariance matrix is considered.

Preliminary analysis showed the statistical significance of skills' level impact on wage level in the analysed set of countries. The value of estimated returns to education rate vary from $17 \%$ in Scandinavian countries to $40 \%$ and more in Southern Europe countries.

In general, countries with low estimated returns to education can be characterized by higher labour force participation rates, better educated population, higher public expenditures on education and lower dispersion of wages. Moreover, in this group of countries, work experience seems to be much more valuable compared to the remaining countries.

The conducted analyses indicate serious concerns about the stochastic structure imposed in a system of regressions applied for country comparisons. The estimates of parameters of equations, describing return on education effect, vary across countries. However, for predominant cases its differences are not statistically significant when simple stochastic assumptions, imposing no correlations between countries, are considered. The contemporaneous correlations of error terms in the SURE system are empirically supported. Also, the rich parameterisation of the covariance matrix of contemporaneous relations reduced statistical uncertainty. Hence, the inferences about return on education effect in a set of countries become more diverse. In the case of the independent regressions, the results of tests about the differences between parameters describing return to education 
effect, is unclear and produces great uncertainty. Given the more complex stochastic structure of dependence between error terms it was possible to classify a set of countries in a nontrivial way. The testing procedures distinguish five separable groups of countries with different return on education effect. Hence, the linkages between countries, expressed in the model by contemporaneous correlations of the error term, is empirically important and provide much more interesting results about functions of interest, making the statistical inference about regression parameters unchanged. Consequently, testing the heterogeneity of parameters in the Mincer regressions is not an easy task and can be performed in the system regression approach with more complicated stochastic assumptions.

The obtained regional differences in rates of return to education as a result of complex stochastic assumptions indicate that the returns to education are higher in the CEE than in the EU15 countries. At any reasonable level of significance we can reject the hypothesis of equality returns to education in these analysed countries. However, the standard assumptions about the stochastic structure (panel OLS estimator) indicate equal returns to education in almost all the countries (except Denmark and Sweden). Thus more rigorous assumptions do allow to conclude that the rates of return to education are the same in emerging and developed countries.

\section{REFERENCES}

Aakvik, A., K. G. Salvanes, K. Vaage, Measuring Heterogeneity in the Returns to Education Using an Education Reform, "European Economic Review”, 54(4),pp. 483-500, 2010.

Bargain, O., Bhaumik, K. S., Chakrabarty, M., Zhao, Z., Earnings Differences between Chinese and Indian Wage Earners, 1987-2004, "Review of Income and Wealth", 55(s1), pp.562-587, 2009.

Becker, G. S., Chiswick, R. B., Education and the Distribution of Earnings, "American Economic Review”, 56, pp.358-369, 1966.

Blundell, R., Dearden, L., Sianesi, B., Evaluating the Effect of Education on Earnings: Models, Methods and Results from the National Child Development Survey, "Journal of the Royal Statistical Society: Series A (Statistics in Society)”, 168(3), pp. 473-512, 2005.

Bolli, T., Zurlinden, M., Measurement of Labour Quality Growth Caused by Unobservable Characteristics, “Applied Economics”, 44.18, pp. 2297-2308, 2012.

Card, D., Estimating the Return to Schooling: Progress on Some Persistent Econometric Problems, "Econometrica", 69(5), pp. 1127-1160, 2001.

Carneiro, P., Heckman, J., The Evidence on Credit Constraints in Postsecondary Schooling, "Economic Journal", 112, pp. 705-734, 2002. 
Chiswick, B. R., Mincer, J., Experience and Distribution of Earnings, IZA Discussion Paper no. 847, 2003.

Dickson, M., Harmon, C., Economic Returns to Education: What We Know, What We Don't Know, and Where We Are Going Some Brief Pointers, "Economics of Education Review", 30, pp. 1118-1122, 2011.

Eric, A., Hanushek, E. A., Zhang, L., Quality-Consistent Estimates of International Returns to Skill, NBER Working Papers 12664, National Bureau of Economic Research, 2006.

Hanushek, E. A., Schwerdt, G., Wiederhold, S., Woessmann, L., Returns to Skills around the World: Evidence from PIAAC, "European Economic Review", 73, pp. 103-130, 2015.

Hanushek, E. A., Woessmann, L., The Economics of International Differences in Educational Achievement, NBER Working Paper no. w15949, National Bureau of Economic Research, 2010.

Hausman, J. A., Taylor, W. E., Panel Data and Unobservable Individual Effects, "Econometrica", 49(6), pp. 1377-1398, 1981.

Heckman, J., Shadow Prices, Market Wages, and Labor Supply, "Econometrica”, 42(4), pp. 679-694, 1974.

Heckman, J., Lochner, L., Todd, P., Earnings Functions, Rates of Return and Treatment Effects: The Mincer Equation and Beyond [in:] Hanushek, A. E., Welch, F. (eds.) Handbook of the Economics of Education 1, pp. 307-458, 2006.

Heckman, J., Lochner, L., Todd, P., Earnings Functions and Rates of Return, "Journal of Human Capital", 2, pp. 1-31, 2008.

Heckman, J., Urzua, S., Comparing \{IV\} with Structural Models: What Simple $\{I V\}$ Can and Cannot Identify, "Journal of Econometrics", 156, pp. 27-37, 2010.

Henderson, D. J., Polachek, W. S., Wang, L., Heterogeneity in Schooling Rates of Return, "Economics of Education Review", 30(6), pp. 1202-1214, 2011.

International Standard Classifications: ISCO-08, International Labour Office, Geneva: ILO, 2012, vol. 1 .

Koop, G. M., Tobias, J., Learning about Heterogeneity in Returns to Schooling, "Journal of Applied Econometrics", 19 (7), pp. 827-849, 2004.

Krueger, A. B., Lindahl, M., Education for Growth: Why and For Whom?, "Journal of Economic Literature", 39, pp. 1101-1136, 2001.

Lacuesta, A., Puente, S., Cuadrado, P., Omitted Variables in the Measurement of a Labor Quality Index: The Case of Spain, "Review of Income and Wealth", 57.1, pp. 84-110, 2011.

Lemieux, T., The Mincer Equation Thirty Years after Schooling, Experience, and Earnings, [in:] Grossbard-Shechtman, S. (ed.), Jacob Mincer, A Pioneer of Modern Labour Economics. Springer Verlag, 2006.

Li, H., Liang, Y., Fraumeni, M. B., Liu, Z., Wang, X., Human Capital in China, 1985-2008, "Review of Income and Wealth", 59, pp. 212-234, 2013.

Li, M., Tobias, L. J., Bayesian Inference in a Correlated Random Coefficients Model: Modeling Causal Effect Heterogeneity with an Application to Heterogeneous Returns to Schooling, "Journal of Econometrics", 162(2), pp. 345-361, 2011.

Mincer, J., Investment in Human Capital and Personal Income Distribution, "Journal of Political Economy”, 66 (4), pp. 281-302, 1958. 
Mincer, J., Schooling, Experience and Earnings, National Bureau of Economic Research, New York, 1974.

Montenegro, C. E., Patrinos, A. H., Comparable Estimates of Returns to Schooling around the World, World Bank Policy Research Working Paper, 7020, 2014.

Moretti, E., Estimating the Social Return to Higher Education: Evidence from Longitudinal and Repeated Cross-sectional Data, "Journal of Econometrics", 121, pp. 175-212, 2004.

Münich, D., Svejnar, J., Terrell, K., Returns to Human Capital under the Communist Wage Grid and during the Transition to a Market Economy, "Review of Economics and Statistics", 87(1), pp. 100-123, 2005.

Newell, A., Reilly, B., The Gender Pay Gap in the Transition from Communism: Some Empirical Evidence, "Economic Systems", 25(4), pp. 287-304, 2011.

Nilsen, Ø. A., Raknerud, A., Rybalka, M., Skjerpen, T., The Importance of Skill Measurement for Growth Accounting, Review of Income and Wealth, 57(2), pp. 293-305, 2011.

Ning, G., Can Educational Expansion Improve Income Inequality? Evidence from the CHNS 1997 and 2006 Data, Economic Systems, 34(4), pp. 397-412, 2010.

Olszak, M., Pipień, M., Cross Country Linkages as Determinants of Procyclicality of Loan Loss Provisions, European Journal of Finance 22 (11), pp. 965-984, 2016.

Pipień, M., Roszkowska, S., Heterogeneity of Convergence in Transition Countries, PostCommunist Economies, 2018.

Psacharopoulos, G., Returns to Investment in Education: A Global Update, "World Development", 22(9), pp.1325-1343, 1994.

Psacharopoulos, G., Patrinos, A. H., Returns to Investment in Education: A Further Update, "Education Economics", 12(2), pp. 111-134, 2004.

Roszkowska, S., Regionalne zróżnicowanie stóp zwrotu z wyksztatcenia w Europie [Regional Diversification of Returns to Education in Europe], „Studia Prawno-Ekonomiczne”, XCIII (93)), pp. 289-299, 2014.

Strauss, H., de La Maisonneuve, Ch., The Wage Premium on Tertiary Education: New Estimates for 21 OECD Countries, OECD, Paris, 2007.

Vujčić, B., Šošić, V., Return to Education and the Changing Role of Credentials in the Croatian Labor Market, “Transition Studies Review”, 16(1), pp. 189-205, 2009.

Willis, R., Rosen, S., Education and Self-Selection, "Journal of Political Economy", 87, pp. 7-S36, 1979.

Zellner, A., An Efficient Method of Estimating Seemingly Unrelated Regressions and Tests for Aggregation Bias, "Journal of the American Statistical Association", 57(298), pp. 348-368, 1962.

Zoghi, C., Measuring Labor Composition: A Comparison of Alternate Methodologies [in:] Abraham, G. K., Spletzer, R. J., Harper, H. (eds.), Labor in the New Economy, pp.457-485. University of Chicago Press, 2010.

Received: April 2016, revised: November 2017 


\section{APPENDIX}

Table 1

ISCO-08 groups and skill levels

\begin{tabular}{l|l}
\hline \multicolumn{1}{c|}{ ISCO-08 major groups } & \multicolumn{1}{c}{ Skill Level } \\
\hline 1 Managers & $3+4$ \\
\hline 2 Professionals & 4 \\
\hline 3 Technicians and Associate Professionals & 3 \\
\hline 4 Clerical Support Workers & 2 \\
\hline 5 Service and Sales Workers & 2 \\
\hline 6 Skilled Agricultural, Forestry and Fishery Workers & 2 \\
\hline 7 Craft and Related Trades Workers & 2 \\
\hline 8 Plant and Machine Operators and Assemblers & 2 \\
\hline 9 Elementary Occupations & 1 \\
\hline 10 Armed Forces Occupation & $1+2+4$ \\
\hline
\end{tabular}

Source: International Standard Classifications: ISCO-08, International Labour Office, Geneva: ILO, 2012, vol. 1.

Table 2

Descriptive statistics of hourly wages in selected EU countries in 2010 (in PPS)

\begin{tabular}{l|r|r|r|r|r}
\hline \multicolumn{1}{c|}{ Country } & Mean & Minimum & Maximum & Variance & $\begin{array}{c}\text { Coefficient } \\
\text { of variation }\end{array}$ \\
\hline Austria & 16.196 & 7.330 & 46.400 & 64.591 & 0.4962 \\
\hline Belgium & 18.741 & 10.010 & 42.140 & 58.243 & 0.4072 \\
\hline Bulgaria & 5.349 & 2.340 & 13.050 & 7.771 & 0.5212 \\
\hline Czech Republic & 8.060 & 3.700 & 20.060 & 14.024 & 0.4646 \\
\hline Denmark & 19.528 & 11.750 & 35.650 & 29.825 & 0.2797 \\
\hline Estonia & 7.552 & 3.160 & 17.840 & 11.965 & 0.4580 \\
\hline Finland & 16.068 & 8.990 & 35.360 & 38.538 & 0.3863 \\
\hline France & 15.106 & 8.080 & 40.320 & 43.449 & 0.4364 \\
\hline Germany & 17.764 & 7.520 & 40.000 & 67.286 & 0.4618 \\
\hline Hungary & 8.055 & 3.760 & 19.730 & 15.993 & 0.4965 \\
\hline Ireland & 19.313 & 10.180 & 40.300 & 58.440 & 0.3958 \\
\hline Italy & 16.040 & 7.690 & 42.550 & 80.968 & 0.5610 \\
\hline Latvia & 6.238 & 3.160 & 13.160 & 5.978 & 0.3920 \\
\hline Netherlands & 16.471 & 7.230 & 32.420 & 34.222 & 0.3552 \\
\hline Poland & 8.821 & 4.080 & 22.620 & 20.516 & 0.5135 \\
\hline Portugal & 11.422 & 4.150 & 31.150 & 54.673 & 0.6474 \\
\hline Romania & 5.903 & 2.450 & 15.250 & 12.481 & 0.5985 \\
\hline Slovakia & 7.703 & 3.790 & 18.970 & 13.479 & 0.4766 \\
\hline Slovenia & 12.708 & 5.760 & 33.910 & 48.510 & 0.5481 \\
\hline Spain & 14.489 & 7.390 & 35.940 & 44.362 & 0.4597 \\
\hline Sweden & 14.651 & 9.550 & 28.050 & 18.079 & 0.2902 \\
\hline United Kingdom & 16.368 & 7.590 & 36.390 & 53.933 & 0.4487 \\
\hline
\end{tabular}

Source: authors' own. 
Table 3

The results of estimation of parameters in Mincer equations in a set of countries and model selection criteria. We put the point estimates, standard errors (in italics) and p-values for zero restriction test of a particular parameter (in square brackets)

\begin{tabular}{|c|c|c|c|c|}
\hline Country & $\alpha_{0 i}$ & $\alpha_{1 i}$ & $\alpha_{2 i}$ & $\alpha_{3 i}$ \\
\hline 1 & 2 & 3 & 4 & 5 \\
\hline \multirow{3}{*}{ Austria } & 0.804517 & 0.331677 & 0.426552 & -0.03883 \\
\hline & 0.218682 & 0.021472 & 0.113136 & 0.01396 \\
\hline & {$[0.000244]$} & [1.32E-49] & {$[0.00017]$} & [0.005487] \\
\hline \multirow{3}{*}{ Belgium } & 1.297771 & 0.285186 & 0.335843 & -0.02938 \\
\hline & 0.142724 & 0.014014 & 0.073839 & 0.009111 \\
\hline & [3.45E-19] & {$[2.72 \mathrm{E}-80]$} & [5.9E-06] & [0.001291] \\
\hline \multirow{3}{*}{ Bulgaria } & 0.322091 & 0.416255 & 0.113577 & -0.01772 \\
\hline & 0.228792 & 0.022465 & 0.118367 & 0.014605 \\
\hline & {$[0.15943$} & {$[2.6 \mathrm{E}-68$} & [0.337467] & [0.22534] \\
\hline \multirow{3}{*}{ Czech Republic } & 0.520228 & 0.346856 & 0.289626 & -0.03328 \\
\hline & 0.229066 & 0.022491 & 0.118508 & 0.014622 \\
\hline & {$[0.023302$} & [1.83E-49] & [0.014658] & ]0.022989] \\
\hline \multirow{3}{*}{ Denmark } & 1.545782 & 0.174215 & 0.437635 & -0.04545 \\
\hline & 0.140934 & 0.013838 & 0.072913 & 0.008997 \\
\hline & [7.53E-27] & [2.09E-34] & [2.51E-09] & [5E-07] \\
\hline \multirow{3}{*}{ Estonia } & 0.737041 & 0.352713 & 0.205628 & -0.03139 \\
\hline & 0.238293 & 0.023397 & 0.123282 & 0.015211 \\
\hline & [0.002023] & [1.68E-47] & {$[0.095563]$} & [0.039248] \\
\hline \multirow{3}{*}{ Finland } & 1.352042 & 0.258832 & 0.319167 & -0.03292 \\
\hline & 0.177835 & 0.017461 & 0.092004 & 0.011352 \\
\hline & [5.48E-14] & [4.25E-46] & [0.000539] & {$[0.003792]$} \\
\hline \multirow{3}{*}{ France } & 1.259472 & 0.292803 & 0.224716 & -0.01589 \\
\hline & 0.159000 & 0.015612 & 0.08226 & 0.01015 \\
\hline & [4.96E-15] & [9.19E-70] & [0.006383] & [0.117705] \\
\hline \multirow{3}{*}{ Germany } & 0.694024 & 0.339402 & 0.54815 & -0.05546 \\
\hline & 0.180304 & 0.017704 & 0.093281 & 0.01151 \\
\hline & {$[0.000124]$} & {$[1.83 \mathrm{E}-72]$} & [5.31E-09] & [1.62E-06] \\
\hline \multirow{3}{*}{ Hungary } & 0.770683 & 0.375923 & 0.068702 & -0.0028 \\
\hline & 0.204335 & 0.020063 & 0.105714 & 0.013044 \\
\hline & [0.000169] & [1.2E-69] & {$[0.515876]$} & [0.830031] \\
\hline
\end{tabular}




\begin{tabular}{|c|c|c|c|c|}
\hline 1 & 2 & 3 & 4 & 5 \\
\hline Ireland & $\begin{array}{c}0.992552 \\
0.171045 \\
{[8.15 \mathrm{E}-09]}\end{array}$ & $\begin{array}{c}0.26368 \\
0.016794 \\
{[4.63 \mathrm{E}-51]}\end{array}$ & $\begin{array}{c}0.571297 \\
0.088491 \\
{[1.51 \mathrm{E}-10]}\end{array}$ & $\begin{array}{c}-0.05996 \\
0.010919 \\
{[4.78 \mathrm{E}-08]}\end{array}$ \\
\hline Italy & $\begin{array}{c}0.652806 \\
0.227626 \\
{[0.004198]}\end{array}$ & $\begin{array}{c}0.340295 \\
0.02235 \\
{[2.38 \mathrm{E}-48]}\end{array}$ & $\begin{array}{c}0.448101 \\
0.117763 \\
{[0.000148]}\end{array}$ & $\begin{array}{c}-0.03797 \\
0.014531 \\
{[0.009065]}\end{array}$ \\
\hline Latvia & $\begin{array}{c}0.856984 \\
0.182072 \\
{[2.78 \mathrm{E}-06]}\end{array}$ & $\begin{array}{c}0.320107 \\
0.017877 \\
{[2.34 \mathrm{E}-64]}\end{array}$ & $\begin{array}{c}0.07136 \\
0.094196 \\
{[0.448842]}\end{array}$ & $\begin{array}{c}-0.01262 \\
0.011623 \\
{[0.277664]}\end{array}$ \\
\hline Netherlands & $\begin{array}{c}0.851423 \\
0.136289 \\
{[5.63 \mathrm{E}-10]}\end{array}$ & $\begin{array}{l}0.248588 \\
0.013382 \\
{[1.3 \mathrm{E}-68]}\end{array}$ & $\begin{array}{c}0.571987 \\
0.07051 \\
{[1.13 \mathrm{E}-15]}\end{array}$ & $\begin{array}{c}-0.05838 \\
0.0087 \\
{[2.88 \mathrm{E}-11]}\end{array}$ \\
\hline Poland & $\begin{array}{c}0.395191 \\
0.227625 \\
{[0.08277]}\end{array}$ & $\begin{array}{c}0.383528 \\
0.02235 \\
{[9.74 \mathrm{E}-60]}\end{array}$ & $\begin{array}{c}0.325102 \\
0.117763 \\
{[0.005849]}\end{array}$ & $\begin{array}{c}-0.0356 \\
0.01453 \\
{[0.014422]}\end{array}$ \\
\hline Portugal & $\begin{array}{c}-0.04775 \\
0.262584 \\
{[0.855722]}\end{array}$ & $\begin{array}{c}0.46068 \\
0.025783 \\
{[4.04 \mathrm{E}-64]}\end{array}$ & $\begin{array}{c}0.463982 \\
0.135849 \\
{[0.000656]}\end{array}$ & $\begin{array}{c}-0.04216 \\
0.016762 \\
{[0.012023]}\end{array}$ \\
\hline Romania & $\begin{array}{c}0.128356 \\
0.269076 \\
{[0.633422]}\end{array}$ & $\begin{array}{c}0.453002 \\
0.02642 \\
{[1.18 \mathrm{E}-59]}\end{array}$ & $\begin{array}{c}0.158483 \\
0.139208 \\
{[0.255132]}\end{array}$ & $\begin{array}{c}-0.01838 \\
0.017177 \\
{[0.284655]}\end{array}$ \\
\hline Slovakia & $\begin{array}{c}0.628832 \\
0.238073 \\
{[0.008355]}\end{array}$ & $\begin{array}{c}0.341852 \\
0.023376 \\
{[5.33 \mathrm{E}-45]}\end{array}$ & $\begin{array}{c}0.223241 \\
0.123168 \\
{[0.070137]}\end{array}$ & $\begin{array}{c}-0.02638 \\
0.015197 \\
{[0.082884]}\end{array}$ \\
\hline Slovenia & $\begin{array}{c}0.764813 \\
0.190327 \\
{[6.19 \mathrm{E}-05]}\end{array}$ & $\begin{array}{c}0.385382 \\
0.018688 \\
{[3.94 \mathrm{E}-82]}\end{array}$ & $\begin{array}{c}0.233162 \\
0.098467 \\
{[0.018031]}\end{array}$ & $\begin{array}{c}-0.01591 \\
0.01215 \\
{[0.190602]}\end{array}$ \\
\hline Spain & $\begin{array}{l}1.181748 \\
0.187973 \\
{[4.4 \mathrm{E}-10]}\end{array}$ & $\begin{array}{c}0.317969 \\
0.018457 \\
{[3.75 \mathrm{E}-60]}\end{array}$ & $\begin{array}{l}0.161371 \\
0.097249 \\
{[0.09728]}\end{array}$ & $\begin{array}{c}-0.0043 \\
0.011999 \\
{[0.720075]}\end{array}$ \\
\hline Sweden & $\begin{array}{c}1.471135 \\
0.14431 \\
{[1.53 \mathrm{E}-23]}\end{array}$ & $\begin{array}{c}0.19044 \\
0.014169 \\
{[1.09 \mathrm{E}-38]}\end{array}$ & $\begin{array}{c}0.324012 \\
0.07466 \\
{[1.53 \mathrm{E}-05]}\end{array}$ & $\begin{array}{c}-0.03441 \\
0.009212 \\
{[0.000196]}\end{array}$ \\
\hline United Kingdom & $\begin{array}{c}0.750457 \\
0.186361 \\
{[5.97 \mathrm{E}-05]}\end{array}$ & $\begin{array}{c}0.34039 \\
0.018298 \\
{[8.86 \mathrm{E}-69]}\end{array}$ & $\begin{array}{c}0.540786 \\
0.096415 \\
{[2.48 \mathrm{E}-08]}\end{array}$ & $\begin{array}{c}-0.06146 \\
0.011896 \\
{[2.76 \mathrm{E}-07]}\end{array}$ \\
\hline \multicolumn{5}{|c|}{ Criteria for model selection } \\
\hline & \multicolumn{2}{|c|}{ Model $M_{0}$} & \multicolumn{2}{|c|}{ Model $M_{1}$} \\
\hline Log-likelihood & \multicolumn{2}{|c|}{543.590} & \multicolumn{2}{|c|}{1889.709} \\
\hline AIC & \multicolumn{2}{|c|}{-289.689} & \multicolumn{2}{|c|}{-1307.193} \\
\hline $\mathrm{BIC}$ & \multicolumn{2}{|c|}{-867.181} & \multicolumn{2}{|c|}{-3097.418} \\
\hline
\end{tabular}

Source: authors' own. 


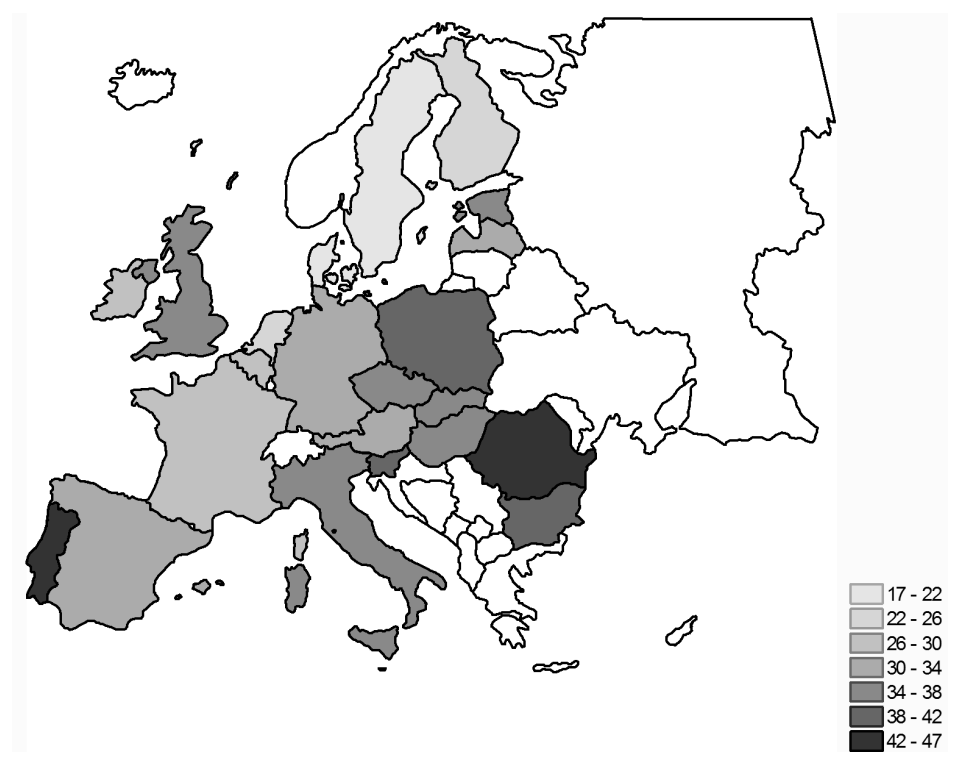

Figure 1. Return to education in 2010 (in pp.)

Source: authors' own.

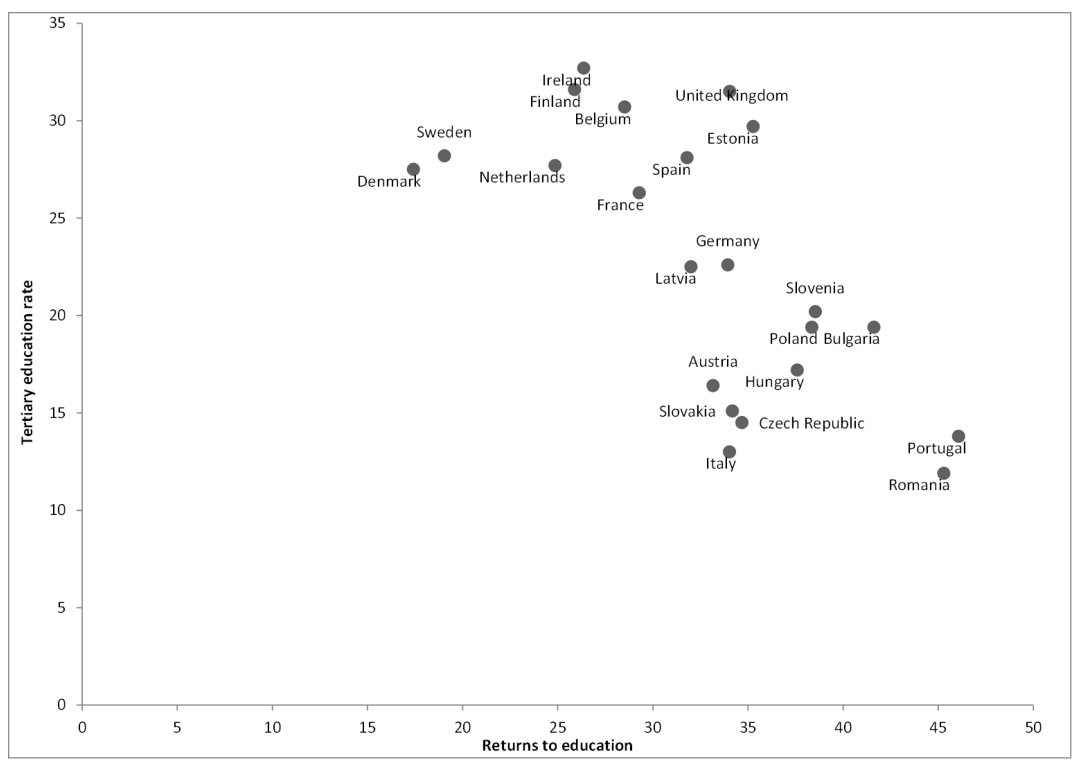

Figure 2. Returns to education vs tertiary education rate (in pp.)

Source: authors' own. 


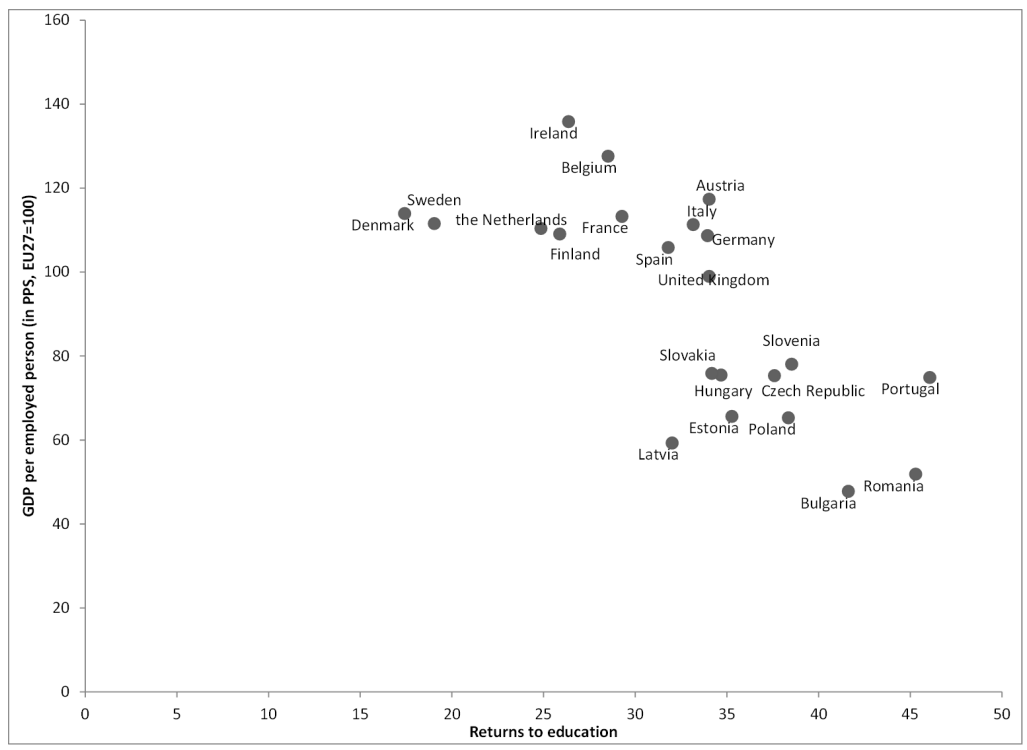

Figure 3. Returns to education vs labour productivity

Source: authors' own.

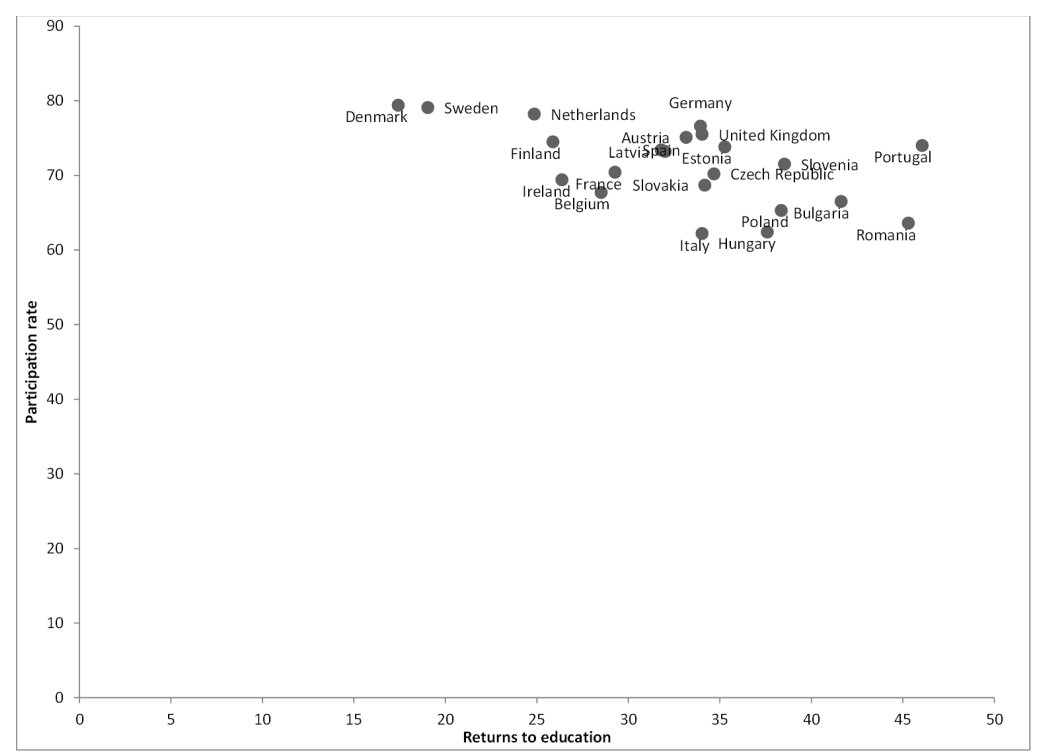

Figure 4. Returns to education vs participation rate

Source: authors' own. 


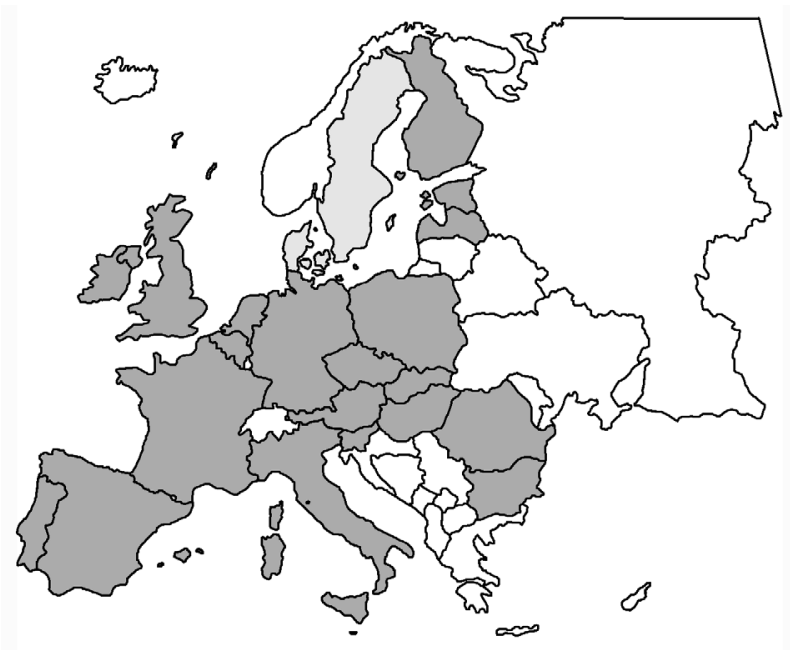

Figure 5. Groups of countries with the same returns to education rates, the case of blockdiagonal variance-covariance matrix $\left(M_{0}\right)$

Source: authors' own.

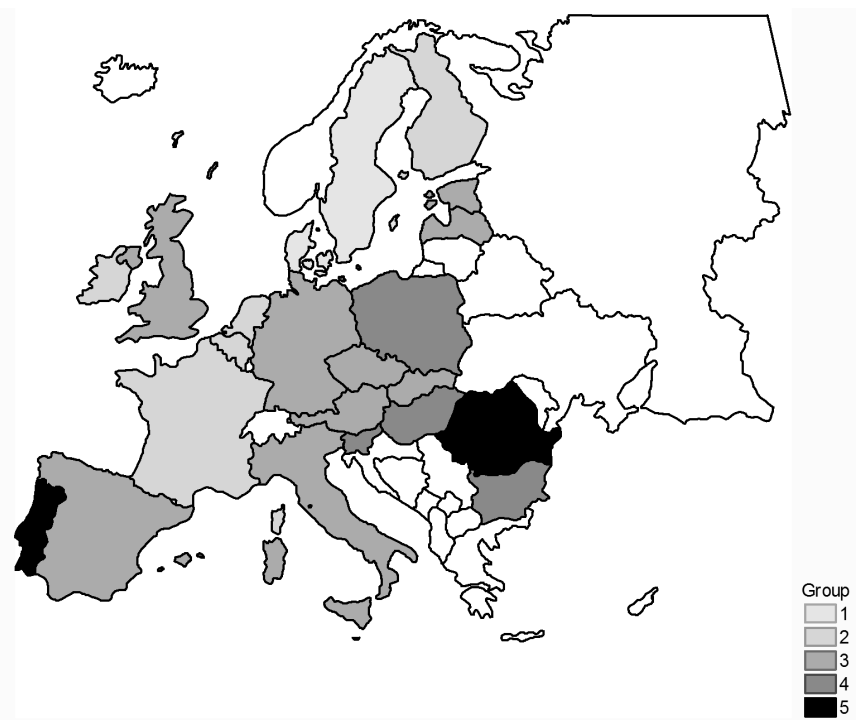

Figure 6. Groups of countries with the same returns to education rates, the case of unrestricted covariance matrix $\left(M_{1}\right)$

Source: authors' own. 


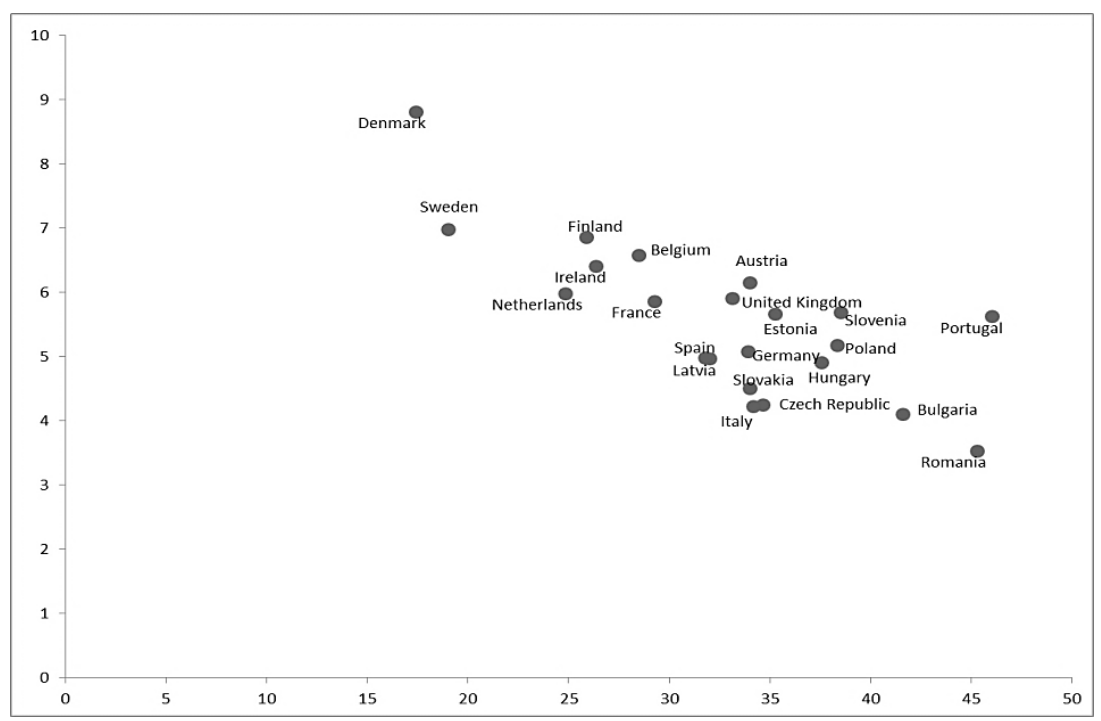

Figure 7. Returns to education vs total public expenditure on education as \% of GDP Source: authors' own.

Table 4

Structure of employees in the population of active enterprises in 2010

\begin{tabular}{l|c|c|c|c|c|c}
\hline \multirow{2}{*}{ Country } & \multicolumn{3}{|c|}{ Number of employees } & \multicolumn{2}{c}{ Percentage shares of employees } \\
\cline { 2 - 7 } & $\begin{array}{c}\text { From 1 to 4 } \\
\text { employees }\end{array}$ & $\begin{array}{c}\text { From 5 to 9 } \\
\text { employees }\end{array}$ & $\begin{array}{c}10 \text { employees } \\
\text { or more }\end{array}$ & $\begin{array}{c}\text { From 1 to 4 } \\
\text { employees }\end{array}$ & $\begin{array}{c}\text { From 5 to 9 } \\
\text { employees }\end{array}$ & $\begin{array}{c}10 \text { employees } \\
\text { or more }\end{array}$ \\
\hline Austria & 2 & 3 & 4 & 5 & 6 & 7 \\
\hline Belgium & 315365 & 274517 & 2391849 & 10.577 & 9.207 & 80.217 \\
\hline Bulgaria & 241786 & 197683 & 2219584 & 9.093 & 7.434 & 83.473 \\
\hline Czech & 267785 & 183967 & 1681362 & 12.554 & 8.624 & 78.822 \\
Republic & 321417 & 272505 & 2957038 & 9.052 & 7.674 & 83.274 \\
\hline Denmark & na & na & na & na & na & na \\
\hline Estonia & 54061 & 42217 & 297586 & 13.726 & 10.719 & 75.556 \\
\hline Finland & 150630 & 124031 & 1144319 & 10.615 & 8.741 & 80.644 \\
\hline France & 1513583 & 1404084 & 12060243 & 10.105 & 9.374 & 80.520 \\
\hline Germany & 2172468 & 1932273 & 21610143 & 8.448 & 7.514 & 84.037 \\
\hline Hungary & 452300 & 220710 & 1626316 & 19.671 & 9.599 & 70.730 \\
\hline Ireland & na & na & na & na & na & na \\
\hline Italy & 1912983 & 1386445 & 8470911 & 16.253 & 11.779 & 71.968 \\
\hline Latvia & 80696 & 65848 & 450843 & 13.508 & 11.023 & 75.469 \\
\hline Netherlands & 407213 & 384481 & 6466974 & 5.610 & 5.297 & 89.093 \\
\hline Poland & na & na & na & na & na & na \\
\hline Portugal & 498132 & 376965 & 2178399 & 16.313 & 12.345 & 71.341 \\
\hline
\end{tabular}




\begin{tabular}{l|r|r|r|r|r|r}
\hline \multicolumn{1}{c|}{1} & \multicolumn{1}{c|}{2} & \multicolumn{1}{c|}{3} & \multicolumn{1}{c|}{4} & \multicolumn{1}{c|}{5} & \multicolumn{1}{c|}{6} & \multicolumn{1}{c}{7} \\
\hline Romania & 506532 & 347287 & 2976298 & 13.225 & 9.067 & 77.708 \\
\hline Slovakia & 145215 & 58634 & 1150572 & 10.722 & 4.329 & 84.949 \\
\hline Slovenia & 91300 & 51853 & 453568 & 15.300 & 8.690 & 76.010 \\
\hline Spain & 2118670 & 1327490 & 8014381 & 18.487 & 11.583 & 69.930 \\
\hline Sweden & 308706 & 233440 & 1989272 & 12.195 & 9.222 & 78.583 \\
\hline $\begin{array}{l}\text { United } \\
\text { Kingdom }\end{array}$ & 2546896 & 1567057 & 17272274 & 11.909 & 7.327 & 80.764 \\
\hline
\end{tabular}

Note: Number of employees is defined as those persons who work for an employer and who have a contract of employment and receive compensation in the form of wages, salaries, fees, gratuities, piecework pay or remuneration in kind. A worker from an employment agency is considered to be an employee of that temporary employment agency and not of the unit (customer) in which she/he works; na - not available; data covers industry, construction and services except insurance activities of holding companies.

Source: Eurostat.

Table 5

Statistical classification of economic activities in the European Community (NACE)

\begin{tabular}{l|l}
\hline \multicolumn{1}{c|}{$\begin{array}{c}\text { NACE } \\
\text { Rev. 2 Code }\end{array}$} & \multicolumn{1}{c}{ Economic activity } \\
\hline A & Agriculture, forestry and fishing \\
\hline B & Mining and quarrying \\
\hline C & Manufacturing \\
\hline D & Electricity, gas, steam and air conditioning supply \\
\hline E & Water supply; sewerage, waste management and remediation activities \\
\hline F & Construction \\
\hline $\mathrm{G}$ & Wholesale and retail trade; repair of motor vehicles and motorcycles \\
\hline $\mathrm{H}$ & Transportation and storage \\
\hline $\mathrm{I}$ & Accommodation and food service activities \\
\hline $\mathrm{J}$ & Information and communication \\
\hline $\mathrm{K}$ & Financial and insurance activities \\
\hline $\mathrm{L}$ & Real estate activities \\
\hline $\mathrm{M}$ & Professional, scientific and technical activities \\
\hline $\mathrm{N}$ & Administrative and support service activities \\
\hline $\mathrm{O}$ & Public administration and defence; compulsory social security \\
\hline $\mathrm{P}$ & Education \\
\hline $\mathrm{Q}$ & Human health and social work activities \\
\hline $\mathrm{R}$ & Arts, entertainment and recreation \\
\hline $\mathrm{S}$ & Other service activities \\
\hline $\mathrm{T}$ & $\begin{array}{l}\text { Activities of households as employers; undifferentiated goods- and } \\
\text { services-producing activities of households for own use }\end{array}$ \\
\hline $\mathrm{U}$ & Activities of extraterritorial organisations and bodies \\
\hline
\end{tabular}

Source: http://ec.europa.eu/eurostat/ramon/nomenclatures/index.cfm?TargetUrl $=A C T$ OTH_DFLT_LAYOUT\&StrNom $=$ NACE_REV2\&StrLanguageCode $=E N$ 
Table 6

Mean and coefficient of variation of hourly wages in selected EU countries in 2010 (in PPS) by level of skills

\begin{tabular}{|c|c|c|c|c|c|c|c|c|}
\hline \multirow[t]{2}{*}{ Country } & \multicolumn{2}{|c|}{$\begin{array}{c}\text { Skill level }=1, \\
n=10\end{array}$} & \multicolumn{2}{|c|}{$\begin{array}{c}\text { Skill level =2, } \\
n=24\end{array}$} & \multicolumn{2}{|c|}{$\begin{array}{c}\text { Skill level }=3 \text {, } \\
\mathbf{n}=10\end{array}$} & \multicolumn{2}{|c|}{$\begin{array}{c}\text { Skill level =4, } \\
\mathbf{n}=\mathbf{2 0}\end{array}$} \\
\hline & mean & $\mathrm{cv}$ & mean & $\mathrm{cv}$ & mean & $\mathrm{cv}$ & mean & $\mathrm{cv}$ \\
\hline Austria & 8.928 & 0.123 & 11.953 & 0.241 & 16.774 & 0.237 & 24.633 & 0.341 \\
\hline Belgium & 11.786 & 0.110 & 14.340 & 0.138 & 18.661 & 0.190 & 27.539 & 0.257 \\
\hline Bulgaria & 2.650 & 0.055 & 3.459 & 0.193 & 5.890 & 0.139 & 8.695 & 0.247 \\
\hline $\begin{array}{l}\text { Czech } \\
\text { Republic }\end{array}$ & 4.359 & 0.119 & 5.856 & 0.205 & 8.701 & 0.144 & 12.235 & 0.283 \\
\hline Denmark & 14.862 & 0.097 & 16.674 & 0.131 & 20.476 & 0.177 & 24.814 & 0.236 \\
\hline Estonia & 4.268 & 0.199 & 5.385 & 0.243 & 7.961 & 0.179 & 11.591 & 0.235 \\
\hline Finland & 10.864 & 0.127 & 12.487 & 0.100 & 15.649 & 0.134 & 23.178 & 0.270 \\
\hline France & 9.400 & 0.080 & 11.258 & 0.100 & 15.239 & 0.157 & 22.509 & 0.301 \\
\hline Germany & 9.592 & 0.127 & 13.063 & 0.187 & 19.445 & 0.267 & 26.651 & 0.278 \\
\hline Hungary & 4.119 & 0.083 & 5.720 & 0.162 & 7.873 & 0.114 & 12.916 & 0.264 \\
\hline Ireland & 12.766 & 0.142 & 14.902 & 0.161 & 19.966 & 0.194 & 27.554 & 0.279 \\
\hline Italy & 8.908 & 0.101 & 11.224 & 0.184 & 15.504 & 0.209 & 25.653 & 0.398 \\
\hline Latvia & 3.620 & 0.129 & 4.672 & 0.171 & 6.800 & 0.150 & 9.147 & 0.179 \\
\hline Netherlands & 10.487 & 0.173 & 13.525 & 0.171 & 17.597 & 0.181 & 22.437 & 0.255 \\
\hline Poland & 4.820 & 0.132 & 5.964 & 0.194 & 8.378 & 0.149 & 14.472 & 0.249 \\
\hline Portugal & 5.004 & 0.109 & 7.015 & 0.263 & 11.387 & 0.173 & 19.937 & 0.364 \\
\hline Romania & 2.614 & 0.043 & 3.808 & 0.243 & 5.638 & 0.119 & 10.196 & 0.302 \\
\hline Slovakia & 4.350 & 0.109 & 5.433 & 0.176 & 8.444 & 0.139 & 11.734 & 0.307 \\
\hline Slovenia & 6.577 & 0.075 & 8.579 & 0.153 & 12.326 & 0.163 & 20.921 & 0.318 \\
\hline Spain & 8.561 & 0.146 & 10.689 & 0.291 & 14.933 & 0.264 & 21.790 & 0.269 \\
\hline Sweden & 10.824 & 0.077 & 12.299 & 0.063 & 15.319 & 0.139 & 19.052 & 0.243 \\
\hline UK & 9.184 & 0.133 & 11.998 & 0.200 & 16.719 & 0.202 & 25.030 & 0.238 \\
\hline
\end{tabular}

Note: Skill level: 1 - elementary qualifications and primary or the first stage of basic education, 2 -secondary levels of education (basic vocational, general and vocational comprehensive) and post- or non-tertiary levels, 3 -first stage tertiary education, 4 -tertiary level of education; $\mathrm{n}$ - no. of observations; mean - average wage in the group; cv coefficient of variation.

Source: authors' own. 
Table 7

Mean and coefficient of variation of hourly wages in selected EU countries in 2010 (in PPS) by age

\begin{tabular}{|c|c|c|c|c|c|c|c|c|c|c|}
\hline \multirow{2}{*}{ Country } & \multicolumn{2}{|c|}{ Age $=2, n=12$} & \multicolumn{2}{|c|}{ Age $=3, n=14$} & \multicolumn{2}{|c|}{ Age $=4, n=14$} & \multicolumn{2}{|c|}{ Age $=5, n=12$} & \multicolumn{2}{|c|}{ Age $=6, n=12$} \\
\hline & mean & $\mathrm{cv}$ & mean & $\mathrm{cv}$ & mean & $\mathrm{cv}$ & mean & $\mathrm{cv}$ & mean & $\mathrm{cv}$ \\
\hline Austria & 11.143 & 0.280 & 14.379 & 0.347 & 16.664 & 0.435 & 18.835 & 0.458 & 20.185 & 0.580 \\
\hline Belgium & 13.983 & 0.242 & 16.811 & 0.327 & 19.209 & 0.377 & 21.859 & 0.405 & 22.084 & 0.438 \\
\hline Bulgaria & 5.422 & 0.481 & 5.710 & 0.604 & 5.371 & 0.538 & 5.217 & 0.500 & 4.961 & 0.519 \\
\hline $\begin{array}{l}\text { Czech } \\
\text { Republic }\end{array}$ & 6.743 & 0.292 & 8.361 & 0.483 & 8.446 & 0.525 & 8.366 & 0.470 & 8.269 & 0.484 \\
\hline Denmark & 14.803 & 0.148 & 19.150 & 0.216 & 21.025 & 0.286 & 21.420 & 0.286 & 21.058 & 0.268 \\
\hline Estonia & 7.523 & 0.403 & 8.279 & 0.492 & 7.831 & 0.485 & 7.320 & 0.461 & 6.639 & 0.466 \\
\hline Finland & 12.863 & 0.212 & 15.641 & 0.331 & 16.885 & 0.405 & 17.491 & 0.427 & 17.396 & 0.423 \\
\hline France & 11.427 & 0.236 & 13.615 & 0.317 & 15.177 & 0.408 & 16.751 & 0.422 & 18.795 & 0.502 \\
\hline Germany & 12.346 & 0.384 & 16.799 & 0.378 & 18.914 & 0.453 & 20.413 & 0.453 & 20.317 & 0.476 \\
\hline Hungary & 6.853 & 0.344 & 8.090 & 0.530 & 7.994 & 0.564 & 8.163 & 0.508 & 9.180 & 0.489 \\
\hline Ireland & 13.883 & 0.244 & 17.645 & 0.282 & 21.081 & 0.375 & 23.346 & 0.403 & 20.595 & 0.413 \\
\hline Italy & 10.145 & 0.195 & 13.310 & 0.328 & 16.645 & 0.527 & 19.619 & 0.536 & 20.834 & 0.585 \\
\hline Latvia & 6.239 & 0.328 & 6.817 & 0.455 & 6.114 & 0.390 & 6.057 & 0.394 & 5.888 & 0.403 \\
\hline Netherlands & 11.374 & 0.244 & 15.759 & 0.257 & 17.756 & 0.340 & 18.936 & 0.339 & 18.436 & 0.355 \\
\hline Poland & 7.009 & 0.322 & 8.866 & 0.500 & 9.386 & 0.566 & 9.173 & 0.505 & 9.572 & 0.570 \\
\hline Portugal & 7.378 & 0.337 & 9.670 & 0.531 & 12.046 & 0.666 & 14.659 & 0.646 & 13.544 & 0.623 \\
\hline Romania & 5.370 & 0.500 & 5.946 & 0.653 & 5.949 & 0.614 & 6.073 & 0.612 & 6.163 & 0.659 \\
\hline Slovakia & 6.664 & 0.302 & 8.184 & 0.527 & 7.925 & 0.522 & 7.787 & 0.479 & 7.840 & 0.502 \\
\hline Slovenia & 9.102 & 0.273 & 11.396 & 0.446 & 12.699 & 0.520 & 14.101 & 0.530 & 16.464 & 0.607 \\
\hline Spain & 10.639 & 0.297 & 12.445 & 0.382 & 14.216 & 0.447 & 16.578 & 0.434 & 18.952 & 0.441 \\
\hline Sweden & 12.005 & 0.133 & 14.394 & 0.235 & 15.589 & 0.314 & 15.752 & 0.329 & 15.401 & 0.301 \\
\hline UK & 12.293 & 0.316 & 16.982 & 0.397 & 17.516 & 0.467 & 18.285 & 0.475 & 16.471 & 0.474 \\
\hline
\end{tabular}

Note: Age: 2 - less than 30 years, 3 - from 30 to 39 years, 4 - from 40 to 49 years, 5 from 50 to 59 years, $6-60$ years or over; $n$ - no. of observations; mean - average wage in the group; cv - coefficient of variation.

Source: authors' own. 
Table 8

Point estimates of correlations (below diagonal in italics) and standard deviations (on the diagonal) of the error terms in case of model $\mathrm{M}_{1}$.

\begin{tabular}{|c|c|c|c|c|c|c|c|c|c|c|c|c|c|c|c|c|c|c|c|c|c|c|}
\hline & $\begin{array}{l}. \frac{\pi}{E} \\
\stackrel{0}{g} \\
Z\end{array}$ & 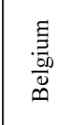 & 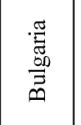 & 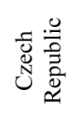 & 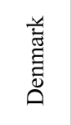 & 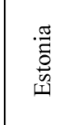 & 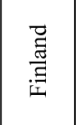 & 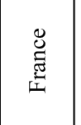 & 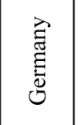 & $\begin{array}{l}\text { 㤐 } \\
\text { 夏 } \\
\text { 至 }\end{array}$ & 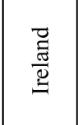 & $\frac{2}{ \pm}$ & 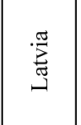 & 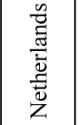 & $\begin{array}{l}\overrightarrow{0} \\
\stackrel{0}{0} \\
\stackrel{0}{0}\end{array}$ & 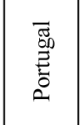 & 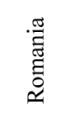 & 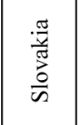 & $\begin{array}{l}. \frac{\pi}{\pi} \\
\frac{0}{\omega} \\
\frac{0}{\infty}\end{array}$ & 雼 & 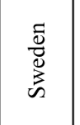 & 光 \\
\hline Austria & 0.186 & & & & & & & & & & & & & & & & & & & & & \\
\hline Belgium & 0.864 & 0.121 & & & & & & & & & & & & & & & & & & & & \\
\hline Bulgaria & 0.628 & 0.603 & \begin{tabular}{|l|}
0.194 \\
\end{tabular} & & & & & & & & & & & & & & & & & & & \\
\hline $\begin{array}{l}\text { Czech } \\
\text { Republic }\end{array}$ & 0.858 & 0.789 & 0.845 & 0.195 & & & & & & & & & & & & & & & & & & \\
\hline Denmark & \begin{tabular}{|l|}
0.859 \\
\end{tabular} & \begin{tabular}{|l|}
0.822 \\
\end{tabular} & \begin{tabular}{|l|}
0.715 \\
\end{tabular} & 0.886 & 0.120 & & & & & & & & & & & & & & & & & \\
\hline Estonia & 0.807 & 0.734 & \begin{tabular}{|l|}
0.851 \\
\end{tabular} & 0.920 & 0.848 & 0.203 & & & & & & & & & & & & & & & & \\
\hline Finland & \begin{tabular}{|l|}
0.789 \\
\end{tabular} & 0.880 & \begin{tabular}{|l|}
0.673 \\
\end{tabular} & 0.803 & 0.908 & 0.799 & \begin{tabular}{|l|}
0.151 \\
\end{tabular} & & & & & & & & & & & & & & & \\
\hline France & 0.800 & 0.858 & 0.564 & 0.750 & 0.800 & 0.692 & 0.861 & 0.135 & & & & & & & & & & & & & & \\
\hline Germany & 0.859 & 0.755 & \begin{tabular}{|l|}
0.674 \\
\end{tabular} & 0.830 & 0.910 & 0.813 & 0.788 & \begin{tabular}{|l|}
0.749 \\
\end{tabular} & \begin{tabular}{|l|}
0.153 \\
\end{tabular} & & & & & & & & & & & & & \\
\hline Hungary & \begin{tabular}{|l|}
0.745 \\
\end{tabular} & \begin{tabular}{|l|}
0.697 \\
\end{tabular} & \begin{tabular}{|l|}
0.815 \\
\end{tabular} & 0.896 & 0.831 & 0.829 & \begin{tabular}{|l|}
0.794 \\
\end{tabular} & \begin{tabular}{|l|}
0.729 \\
\end{tabular} & \begin{tabular}{|l|}
0.759 \\
\end{tabular} & 0.174 & & & & & & & & & & & & \\
\hline Ireland & 0.597 & 0.504 & \begin{tabular}{|l|}
0.232 \\
\end{tabular} & 0.495 & 0.553 & 0.498 & 0.451 & \begin{tabular}{|l|}
0.492 \\
\end{tabular} & \begin{tabular}{|l|}
0.435 \\
\end{tabular} & 0.405 & \begin{tabular}{|l|}
0.145 \\
\end{tabular} & & & & & & & & & & & \\
\hline Italy & \begin{tabular}{|l|}
0.803 \\
\end{tabular} & \begin{tabular}{|l|}
0.823 \\
\end{tabular} & \begin{tabular}{|l|}
0.434 \\
\end{tabular} & 0.726 & 0.743 & 0.594 & \begin{tabular}{|l|}
0.762 \\
\end{tabular} & \begin{tabular}{|l|}
0.796 \\
\end{tabular} & \begin{tabular}{|l|}
0.591 \\
\end{tabular} & 0.654 & 0.671 & \begin{tabular}{|l|}
0.193 \\
\end{tabular} & & & & & & & & & & \\
\hline Latvia & 0.779 & 0.663 & \begin{tabular}{|l|}
0.833 \\
\end{tabular} & \begin{tabular}{|l|}
0.896 \\
\end{tabular} & 0.825 & 0.916 & 0.726 & 0.621 & \begin{tabular}{|l|}
0.783 \\
\end{tabular} & 0.833 & 0.491 & 0.556 & 0.155 & & & & & & & & & \\
\hline Netherlands & 0.781 & 0.626 & \begin{tabular}{|l|}
0.495 \\
\end{tabular} & 0.765 & 0.808 & 0.674 & 0.677 & 0.681 & \begin{tabular}{|l|}
0.779 \\
\end{tabular} & 0.689 & 0.637 & 0.694 & 0.694 & 0.116 & & & & & & & & \\
\hline Poland & 0.802 & 0.828 & \begin{tabular}{|l|}
0.723 \\
\end{tabular} & 0.857 & 0.805 & 0.833 & 0.830 & \begin{tabular}{|l|}
0.780 \\
\end{tabular} & \begin{tabular}{|l|}
0.685 \\
\end{tabular} & 0.814 & \begin{tabular}{|l|}
0.597 \\
\end{tabular} & 0.775 & 0.780 & 0.615 & \begin{tabular}{|l|}
0.193 \\
\end{tabular} & & & & & & & \\
\hline Portugal & 0.758 & 0.756 & \begin{tabular}{|l|}
0.522 \\
\end{tabular} & 0.718 & 0.715 & 0.632 & 0.686 & 0.714 & \begin{tabular}{|l|}
0.593 \\
\end{tabular} & 0.662 & 0.653 & 0.832 & 0.634 & 0.695 & \begin{tabular}{|l|}
0.731 \\
\end{tabular} & 0.223 & & & & & & \\
\hline Romania & \begin{tabular}{|l|}
0.687 \\
\end{tabular} & 0.728 & \begin{tabular}{|l|}
0.867 \\
\end{tabular} & \begin{tabular}{|l|}
0.804 \\
\end{tabular} & 0.677 & \begin{tabular}{|l|}
0.774 \\
\end{tabular} & 0.718 & 0.611 & \begin{tabular}{|l|}
0.627 \\
\end{tabular} & 0.779 & 0.166 & 0.562 & 0.726 & 0.431 & 0.755 & 0.559 & 0.229 & & & & & \\
\hline Slovakia & 0.770 & 0.770 & \begin{tabular}{|l|}
0.875 \\
\end{tabular} & \begin{tabular}{|l|}
0.949 \\
\end{tabular} & 0.870 & \begin{tabular}{|l|}
0.886 \\
\end{tabular} & \begin{tabular}{|l|}
0.832 \\
\end{tabular} & 0.756 & \begin{tabular}{|l|}
0.804 \\
\end{tabular} & 0.877 & 0.365 & 0.654 & 0.884 & 0.692 & 0.817 & 0.675 & 0.824 & \begin{tabular}{|l|}
0.202 \\
\end{tabular} & & & & \\
\hline Slovenia & 0.738 & 0.847 & \begin{tabular}{|l|}
0.598 \\
\end{tabular} & 0.758 & 0.708 & 0.633 & 0.771 & 0.826 & \begin{tabular}{|l|}
0.605 \\
\end{tabular} & 0.750 & 0.404 & 0.842 & 0.582 & 0.562 & 0.833 & 0.781 & 0.708 & 0.769 & 0.162 & & & \\
\hline Spain & 0.845 & 0.835 & \begin{tabular}{|l|}
0.637 \\
\end{tabular} & 0.816 & 0.795 & 0.828 & 0.757 & \begin{tabular}{|l|}
0.759 \\
\end{tabular} & \begin{tabular}{|l|}
0.729 \\
\end{tabular} & 0.675 & 0.608 & 0.726 & 0.752 & 0.667 & 0.807 & 0.727 & 0.688 & 0.726 & 0.654 & \begin{tabular}{|l|l|}
0.160 \\
\end{tabular} & & \\
\hline Sweden & \begin{tabular}{|l|}
0.746 \\
\end{tabular} & 0.805 & \begin{tabular}{|l|}
0.656 \\
\end{tabular} & 0.800 & 0.912 & \begin{tabular}{|l|}
0.743 \\
\end{tabular} & \begin{tabular}{|l|}
0.929 \\
\end{tabular} & \begin{tabular}{|l|}
0.845 \\
\end{tabular} & \begin{tabular}{|l|}
0.822 \\
\end{tabular} & 0.759 & 0.380 & 0.709 & 0.687 & \begin{tabular}{|l|}
0.682 \\
\end{tabular} & 0.715 & 0.612 & 0.639 & \begin{tabular}{|l|}
0.819 \\
\end{tabular} & 0.705 & 0.718 & \begin{tabular}{|l|l|}
0.123 \\
\end{tabular} & \\
\hline UK & 0.709 & 0.613 & \begin{tabular}{|l|}
0.432 \\
\end{tabular} & 0.668 & 0.726 & 0.642 & 0.658 & \begin{tabular}{|l|}
0.657 \\
\end{tabular} & \begin{tabular}{|l|}
0.687 \\
\end{tabular} & 0.632 & 0.693 & 0.654 & 0.618 & 0.806 & 0.656 & 0.662 & 0.370 & 0.596 & 0.542 & 0.656 & 0.628 & 0.158 \\
\hline
\end{tabular}

Note: Estimates obtained on the basis of matrix $\mathrm{S}$ of sample variances and covariances of OLS residuals according to the Zellner (1962) method; see formula (4). In the case of model $M_{0}$ all of the diagonal elements are zero.

Source: authors' own. 